\title{
Retrofitting suspended timber ground-floors; comparing aggregated and disaggregated evaluation methods
}

\section{David Glew, David Johnston, Dominic Miles-Shenton \& Felix Thomas}

To cite this article: David Glew, David Johnston, Dominic Miles-Shenton \& Felix Thomas (2019): Retrofitting suspended timber ground-floors; comparing aggregated and disaggregated evaluation methods, Building Research \& Information, DOI: 10.1080/09613218.2019.1681927

To link to this article: https://doi.org/10.1080/09613218.2019.1681927

\section{Published online: 29 Oct 2019.}

Submit your article to this journal ¿

Цll Article views: 71

Q View related articles ¿

View Crossmark data \lceil 


\title{
Retrofitting suspended timber ground-floors; comparing aggregated and disaggregated evaluation methods
}

\author{
David Glew, David Johnston, Dominic Miles-Shenton and Felix Thomas \\ Leeds Sustainability Institute, Leeds Beckett University, Leeds, UK
}

\begin{abstract}
It is estimated that around $80 \%$ of UK dwellings have uninsulated ground floors, representing a significant heat loss mechanism in these buildings. In this research, an aggregated assessment of dwelling heat loss was made using the electric coheating test before and after a ground floor retrofit took place. Heat loss was reduced by $24 \%(43 \pm 18 \mathrm{~W} / \mathrm{K})$ indicating that suspended timber ground floor retrofits could improve thermal comfort for occupants and contribute to government domestic energy efficiency policy targets. The findings indicate that disaggregated evaluation methods, such as spot heat flux density measurements, may overestimate the benefits of fabric retrofits. Aggregate methods may therefore be more appropriate tools with which to evaluate retrofits. The U-value improvement resulting from the suspended timber ground floor insulation retrofit, derived via aggregate measurement, was $0.55 \mathrm{~W} / \mathrm{m}^{2} \mathrm{~K}$. Disaggregated spot heat flux density measurements indicated the improvement was $0.89 \mathrm{~W} /$ $\mathrm{m}^{2} \mathrm{~K}$. This research also indicates that Energy Performance Certificates, are unlikely to provide a reliable estimate of energy savings, because they rely on default assumptions for fabric U-Values and ventilation rates. This has implications for policy evaluations as well as householders, who may be excluded from financial support for retrofits.
\end{abstract}

\section{ARTICLE HISTORY}

Received 31 January 2019

Accepted 11 October 2019

\section{KEYWORDS}

Retrofit; building

performance; thermal retrofits; whole house heat loss; floor insulation; coheating

\section{Introduction}

The UK Government has committed to reduce greenhouse gas (GHG) emissions by $80 \%$ by 2050 (Climate Change Act, 2008). Dwellings are responsible for around $25 \%$ of the UK's GHG emissions (CCC, 2016) and space heating can account for over half of this (Palmer \& Cooper, 2013). Consequently, considerable effort has been made to retrofit dwellings in the UK. However, the quality of the retrofits undertaken have often fallen short of the intended standards. This has resulted in performance gaps and unintended consequences that have been the subject of much government and academic research (Elsharkawy \& Rutherford, 2018; Gupta, Gregg, Passmore, \& Stevens, 2015; Hall, Casey, Loveday, \& Gillott, 2013; Hamilton et al., 2016; Hong, Oreszczyn, \& Ridley, 2006; Innovate UK, 2016; Ma, Cooper, Daly, \& Ledo, 2012; Rodrigues, White, Gillott, Braham, \& Ishaque, 2018).

Various policies have been introduced by the UK Government to reduce domestic GHG emissions: the Community Energy Saving Programme (CESP); the Carbon Emissions Reduction Target (CERT); the Energy Company Obligation (ECO1 and 2); and, the Green Deal (OFGEM, 2013a, 2013b, 2015). As shown in Figure 1, these policies have resulted in millions of dwellings being retrofitted. However, cavity wall insulation, loft insulation and new gas boilers dominate the retrofit market. Increasing the variety of retrofit measures that take place across the building stock can be challenging, because dwellings can often become 'locked in' to partial retrofits, reducing the likelihood of other retrofits taking place (Ürge-Vorsatz \& Tirado Herrero, 2012).

It is estimated that almost 11 million dwellings have uninsulated suspended timber ground floors in the UK (Shorrock \& Utley, 2005). Despite this, suspended timber ground floor retrofits do not contribute in any meaningful way to current policy. A major barrier to ground floor insulation is the fact that it is considered disruptive and are generally only cost-effective if undertaken when refurbishing the existing ground floor (Roberts, 2008; Shorrock \& Utley, 2005). Furthermore, although ground floor insulation is now classified as an approved measure in ECO policy, meaning that it can be installed in homes as a single measure (BEIS, 2017a), it was previously classified as a 'secondary measure', and as such it could only be installed alongside a 'primary measure', e.g. loft or wall insulation, to 


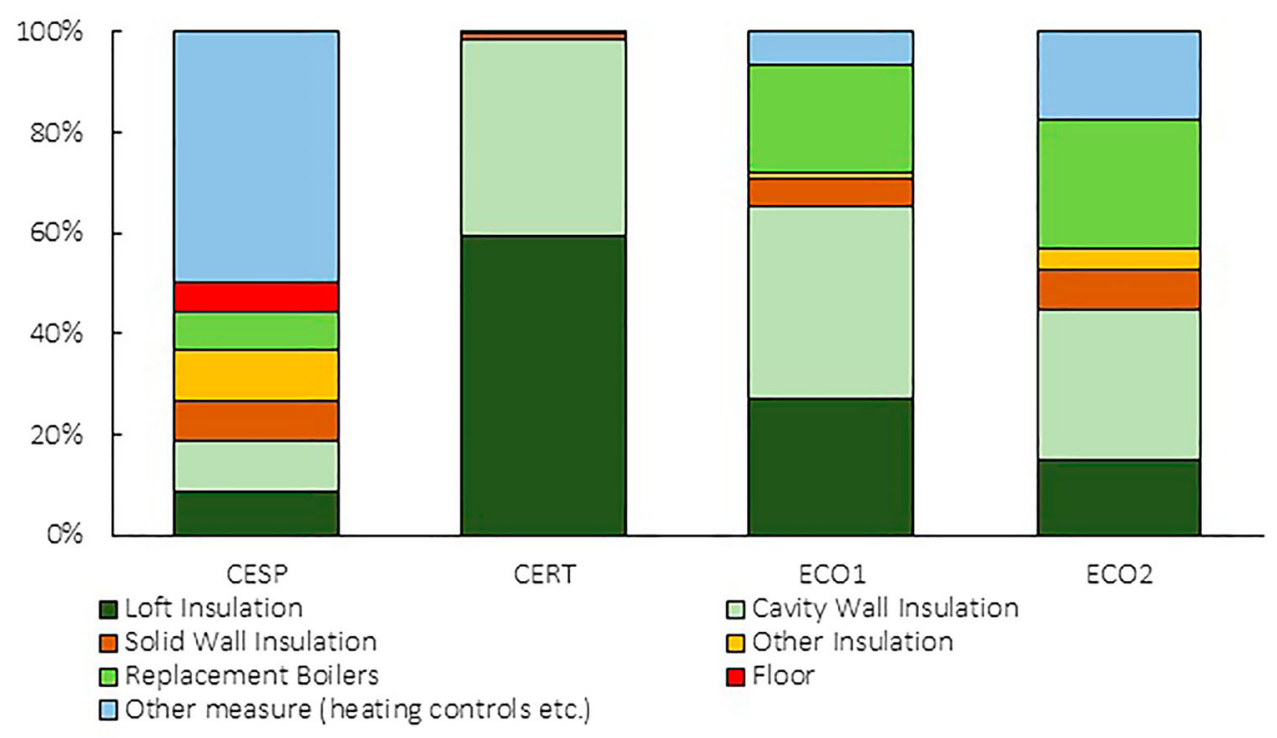

Figure 1 . Retrofit measures installed via Government Schemes (excluding low energy lighting and double glazing).

qualify for funding (OFGEM, 2017). Additionally, retrofits seldom included secondary measures (BEIS, 2017b), despite whole house retrofits being more effective at reducing fuel bills and improving occupant comfort (Innovate UK, 2016). Consequently, despite ground floor insulation being recommended in 200,000 Green Deal surveys, it was rarely installed and accounted for less than $0.5 \%$ of all of the measures undertaken via the ECO scheme (Pelsmakers, 2016).

\section{Suspended timber ground floor retrofits}

The Energy Savings Trust (EST) have estimated that the costs of ground floor retrofits are between $£ 24$ and $£ 55$ per $\mathrm{m}^{2}$ based on a standard $80 \mathrm{~m}^{2}$ semi-detached home with a $40 \mathrm{~m}^{2}$ ground floor area (EST, 2017). This cost depends upon the standards and materials used and does not include any potential remedial costs. In contrast, the Department for Business, Enterprise and Industrial Strategy (BEIS) have estimated that for the same size and form of dwelling, suspended timber ground floor retrofits could cost as much as $£ 87-£ 208$ per $\mathrm{m}^{2}$, although this would be lower if floorboards had already been lifted to undertake other renovation work, or if a suitable crawl space was available, meaning only some of the floorboards may need to be lifted (Palmer, Livingstone, \& Adams, 2017). Despite these variations in cost, the estimates are significantly less than that associated with installing other retrofit measures, such as internal wall insulation or double glazing (SWEET, 2014).

In addition to cost, there are a number of other potential barriers to suspended timber ground floor insulation. For example, the lack of consumer awareness of retrofits (Blumstein, Krieg, Schipper, \& York, 1980). However, the extent of unfamiliarity is difficult to generalize, because knowledge of retrofits varies greatly amongst stakeholders (Fylan et al., 2016). Disturbance to householders is also a barrier, particularly as traditional methods tend to require floors to be lifted, making parts of homes inaccessible during the retrofit (Gupta et al., 2015). Consequently, it is thought that ground floors are only insulated when they are replaced as part of larger home improvement projects (Roberts, 2008). In addition, there are also practical barriers to overcome. For instance, the underfloor void must be sufficiently large to enable the installation to take place and still ensure adequate ventilation to the underfloor area.

A YouGov Omnibus survey (funded by insulation manufacturers) of home owners living in pre-1919 properties found that there were three main barriers to adopting energy efficiency measures; (i) cost, (ii) lack of information and (iii) disruption (Mott McDonald, 2013). However, research in New Zealand indicates that occupants prefer to have ground floor insulation over other measures (Phillips, 2012). The reasons for this may be linked to the physiological observation and comfort condition that people prefer a cool head and warm feet (Cheng, Lin, \& Fong, 2015). One of the main occupant drivers to insulate homes is thought to be to reduce draughts (Blumstein et al., 1980), because draughts around feet have a disproportionate effect on perceptions of thermal comfort (Schiavon, Rim, Pasut, \& Nazaroff, 2016). Furthermore, simulations have shown that, in addition to reducing heat loss, retrofitting 
ground floors results in increases in floor surface temperatures and occupant comfort (Hall et al., 2013).

\section{Measuring the impact of ground floor insulation}

In 1985, the Building Regulations for England and Wales stipulated, for the first time, a maximum ground floor Uvalue of $0.45 \mathrm{~W} / \mathrm{m}^{2} \mathrm{~K}$ (Killip, 2005). For new build homes, the latest editions of Approved Document Part L1A sets the maximum allowable ground floor U-value at $0.25 \mathrm{~W} / \mathrm{m}^{2} \mathrm{~K}$ (NBS, 2014). Heat loss via ground floors in homes built prior to these dates is difficult to characterize, due to differences in their junction designs, floor coverings, the floor perimeter to area ratio, underfloor void ventilation rates, seasonal variations in ground temperature and the extent to which other building elements are insulated. Estimates of the proportion of a dwelling's total heat loss that could be attributed to ground floors range vary and range from as low as 10\% (NEF, Undated) and 25\% (Harris \& Dudek, 1997), up to as much as $60 \%$ (EST, 2003).

A number of attempts have been made to empirically quantify the scale of the reduction in U-Value that could be achieved by retrofitting a suspended timber ground floor using a series of in situ point heat flux measurements (see Farmer et al., 2017; Pelsmakers, 2016). In one study, the reductions in U-value ranged from $65 \%$ to $92 \%$, depending on the specification of the retrofit (Pelsmakers, 2016), whilst in another study a $79 \%$ reduction in U-value was achieved where $200 \mathrm{~mm}$ of mineral wool was installed (Farmer et al., 2017). It has also been observed that the heat flow across the surface of suspended timber ground floors is heterogeneous (Pelsmakers et al., 2017) due to the turbulent movements of gas below and neighbouring the floor and range of conductivity within the floor and abutting elements. To account for this heterogeneity, a large number of spot heat flux density measurements may be needed to estimate the aggregate heat flow through the whole floor. Heterogeneous heat flow has also been observed in other building fabric elements, such as solid walls (BRE, 2014). However, installing large arrays of heat flux sensors on individual building elements in field tests is not always achievable or practical. In order to overcome this, thermography is often used to select representative measurement locations for a much smaller number of spot heat flux measurements (BRE, 2016; Farmer et al., 2017; Marshall et al., 2017).

The performance of suspended timber ground floors is influenced by a number of factors, including edge effects; (the extent of thermal bridging at the edges varies according to the floor perimeter); its design; the location, size and number of airbricks in the floor voids; and ventilation pathways around the floor junctions, which can result in complex heat loss paths (Pelsmakers et al., 2017). Furthermore, increasing the ventilation rate in the underfloor void increases the rate of conductive heat loss through the floor, as colder air is introduced into the void (Harris \& Dudek, 1997). Heat flux density measurements cannot directly measure the full extent of thermal bridging particularly at corners and edges. Thus, it is not clear whether either using intensive arrays of spot heat flux density measurements, nor using a fewer number of targeted heat flux density measurements at representative locations, can appropriately capture and account for all of the conductive heat losses associated with suspended timber ground floors.

Additionally, suspended timber ground floor retrofits can reduce convective heat flow by reducing infiltration between and around the floor boards. The effect of suspended timber ground floor retrofits on infiltration rates in dwellings has not been widely measured, though may be less predictable than conductive heat losses, as it is more context-specific. Thus, the impact of suspended timber ground floor insulation on airtightness is relatively uncertain; one study observed effectively no change following retrofit (Pelsmakers, 2016), while another reported an $8 \%$ reduction in infiltration rate (Farmer et al., 2017). Since infiltration can have an important impact on overall dwelling heat loss (Hens, Janssens, Depraetere, Carmeliet, \& Lecompte, 2007), this is an area that requires further research.

Techniques are available that are capable of measuring infiltration rates, using one of the most common techniques, the blower door method. However, this method is not capable of identifying the extent of changes in convective heat loss following retrofits (ATTMA, 2016). Since neither heat flux density nor infiltration measurements can account for all the complexities of heat loss in a dwelling (e.g. thermal bridging and convective heat loss), adopting an aggregate approach to evaluating the benefits of a retrofit, may be a more accurate approach to undertake, to determine the impact on the whole building.

One such aggregate approach that was adopted by the UK Government for their Building Performance Evaluation Programme, ${ }^{1}$ is the electric coheating test (Johnston, Miles-Shenton, Farmer, Wingfield, \& Bell, 2013). This is a quasi-steady-state test that is capable of measuring the aggregate (fabric and infiltration) whole-house Heat Transfer Coefficient (HTC) of a building in Watts per Kelvin (Bauwens and Roels, 2014; Bauwens, Standaert, \& Delcuve, 2012; Everett, 1985; Johnston et al., 2013; Siviour, 1981; Sonderegger, Condon, \& Modera, 1980). The electric coheating test has become the standard test for evaluating the aggregate fabric thermal performance of buildings. In 
addition, when it is combined with spot in situ U-value measurements, air pressurization tests and thermography, an estimate of where the heat loss occurs within the building can also be made (Alexander \& Jenkins, 2015; Bauwens, et al., 2012; Guerra-Santin, Tweed, Jenkins, \& Jiang, 2013; Jack, Loveday, Allinson, \& Lomas, 2018). Limitations associated with the electric coheating test include the length of the test duration (7 days or more), the requirement for the test dwelling to be unoccupied throughout the test period, the tests being undertaken only during the space heating season (October to March in the UK), the costs associated with undertaking the test and a lack of experienced testers.

This paper investigates the impact of a suspended timber ground floor retrofit using two separate measurement approaches: an aggregate method involving the electric coheating test, and a disaggregate approach comprising heat flux density measurements and air pressurization tests. A comparison is undertaken between the two measurement approaches to determine the most appropriate approach and accurate method to adopt when evaluating fabric insulation retrofits.

\section{Method}

\section{The case study dwelling and retrofit}

The test dwelling used in the research was a 1-bedroom bungalow (see Figure 2). There are around 2 million bungalows in the UK (DCLG, 2016), of which around $12 \%$ are 1-bedroomed (VOA, 2014). Bungalows have a large floor area to heat loss area ratio, so may receive proportionally greater benefits from suspended timber ground floor insulation than other dwelling forms. Therefore, caution must be applied when attempting to extrapolate any potential benefits found in this study to the UK housing stock, especially as over half of existing dwellings either have solid ground floors or insulated suspended ground floors (Shorrock \& Utley, 2005).

The case study dwelling has a ground floor area of $44 \mathrm{~m}^{2}$, and is a stepped and staggered end-terrace bungalow, which was built in the 1960s and is orientated East to West. The Northside of the dwelling is sheltered by a separate group of stepped and staggered terraced bungalows. The external walls are of traditional brick and block cavity construction, wet plastered internally, with the $60 \mathrm{~mm}$ external wall cavity previously retro-filled with mineral fibre insulation. The dwelling has a cold pitched roof, with $200 \mathrm{~mm}$ mineral wool insulation located at the ceiling level. It is double-glazed throughout and has an uninsulated suspended timber ground floor. A concrete stepped raft foundation is located beneath the floor, resulting in a $660 \mathrm{~mm}$ crawl space. Floor joists run east to west and are supported on honeycomb brick sleeper walls (see Figure 2). Five $229 \times 76 \mathrm{~mm}\left(9^{\prime \prime} \times 3^{\prime \prime}\right)$ airbricks are located on the east and west elevation (three on the east and two on the west), providing underfloor ventilation. The cavity party wall is of block construction, wet plastered internally, and has a $60 \mathrm{~mm}$ unfilled cavity. Purpose provided ventilation is achieved via trickle vents on the window heads and intermittent extract fans in the kitchen and bathroom.

The retrofit consisted of a robotic device ${ }^{2}$ spraying closed cell polyurethane (PU) foam (BASF Elastospray) to the underside of the suspended timber floor (Holloway, Childs, \& Julia, 2016a, 2016b). To achieve a target U-Value of $0.2 \mathrm{~W} / \mathrm{m}^{2} \mathrm{~K}, 130 \mathrm{~mm}$ of insulation was applied between the joists, and $30 \mathrm{~mm}$ over the underside of the $100 \mathrm{~mm}$ deep joists, following the process outlined in the BBA Agrément Certificate 17/5440. Before and after laser scanning was used to validate that the installation thicknesses were achieved to $\pm 10 \mathrm{~mm}$. The PU foam was designed to set in $60 \mathrm{~s}$, and has a manufacturer stated aged thermal conductivity of between 0.025 and $0.028 \mathrm{~W} / \mathrm{mK}$. As part of the manufacturer's installation instructions, additional spraying was also applied where any air leakage linking

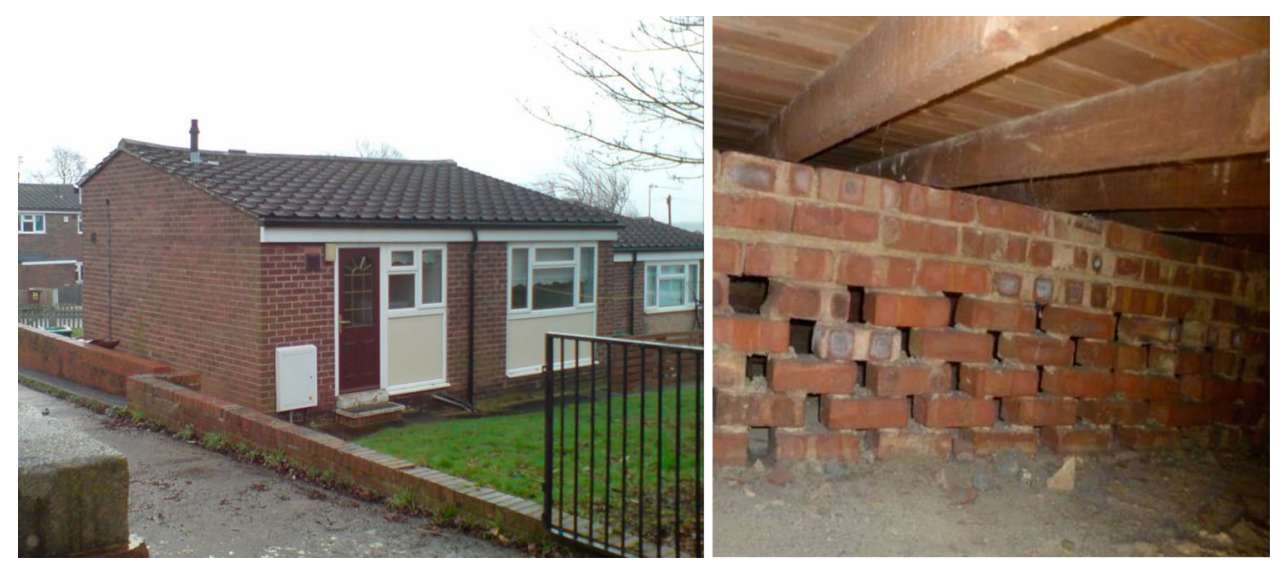

Figure 2 . West-facing elevation of the case study dwelling (left) and honeycomb sleeper walls in the under floor void (right). 
the main dwelling to the underfloor void was observed. For example, around the service penetrations located behind the kitchen sink unit.

The building performance evaluation tests were undertaken on the case study dwelling between the 18th February and the 28th March, resulting in 23 days of pre- and 10 days of post-retrofit data, with 6 days for the retrofit and test set up. The following sections describe the individual tests that were undertaken.

\section{Air pressurization tests and leakage detection}

A series of air pressurization tests were performed according to ATTMA Technical Standard L1 testing protocol (ATTMA, 2016), which has an uncertainty factor due to environmental conditions of normally less than $10 \%$ (BSI, 2014). The average of the pressurized and depressurized tests was calculated in accordance with CIBSE TM 23 (CIBSE, 2000). During depressurization, thermal imaging was used to identify air leakage points and pathways.

The measured mean air change rates obtained from the air pressurization tests were used to approximate the natural annual average background ventilation by dividing the air change rate at $50 \mathrm{~Pa}\left(\mathrm{~N}_{50}\right)$ by 20 . This procedure is commonly known as Sherman's ratio or the rule-of-20 (Jones, Goodhew, \& de Wilde, 2016; Sherman, 1987). In the UK this is conventionally applied to air permeability $\left(\mathrm{Q}_{50} / 20\right)$, rather than air leakage $\left(\mathrm{N}_{50} / 20\right)$ to calculate an average annual infiltration rate for a dwelling, and is contained within the Government's Standard Assessment Procedure (SAP) (BRE, 2012), which forms an integral part of Part L1A of the Building Regulations (NBS, 2014).

\section{Heat flux density measurements}

Hukseflux HFP01 sensors were used to measure heat flux density in $\mathrm{W} / \mathrm{m}^{2}$. Representative locations for heat flux sensor placement were identified using thermography to ensure that thermal bridges or infiltration pathways were avoided. Heat flux density and the corresponding internal and external air temperature measurements were used to calculate an in situ air-to-air U-value for each HFP using the average method contained within BS ISO 9869-1: 2014. Based upon the quadrature sum of the individual errors, this results in a total uncertainty of $14 \%$ (BSI, 2014). The voltage induced by the HFPs was recorded at ten-minute intervals using an Eltek Squirrel $801 / 851$ data logger.

Thermography was used to aid the positioning of the HFPs, resulting in informed indicative point U-values being measured for each thermal element (external wall, external windows, external door, ceiling, party wall and ground floor). This approach was undertaken to enable a pre- and post-retrofit comparison of the indicative Uvalues to be undertaken, so that any change in the measured HTC could be attributed to the application of the retrofit floor insulation, rather than changes to the performance of other elements of the building fabric. Selecting locations for the indicative measurements was limited by obstructions, including fenestrations and built-in cupboards. Despite this, four representative locations were identified for the external wall, which were sufficiently far away from the edges of the wall to ensure that the influence of thermal bridging would be minimized. This resulted in two HFPs being placed on the North wall in the kitchen, two being located on the West wall, one in the kitchen and the other in the bedroom. The party wall had no obstructions, so three HFPs were located in representative locations in each of the lounge and bedroom walls. However, due to access restrictions, it was not possible to measure the internal temperatures experienced in the adjacent dwelling, either pre- or post-retrofit. Consequently, it was not possible to calculate an indicative in situ $\mathrm{U}$-value for the party wall during the test period.

Centre pane heat flux measurements were also undertaken for each of the kitchen door, lounge and bedroom windows. However, thermography revealed that the ceiling had two distinct heat flow patterns, resulting from missing insulation around its perimeter. Thus, heat flux was recorded at representative locations on the insulated and uninsulated ceiling in the bedroom and lounge.

Ground floor heat flux measurements were also undertaken for indicative purposes, and again, thermography was used to select locations on the ground floor where heat flow was not being influenced by any unusual airflow or unusual areas of thermal bridging. In total, nine HFPs were placed on the ground floor as per Figure 3; four were positioned close to the geometric

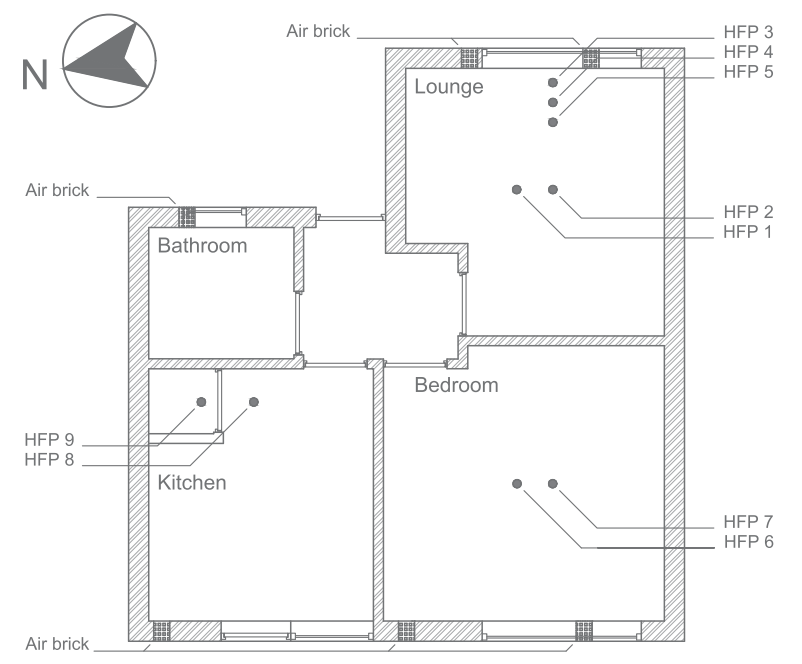

Figure 3 . Ground floor plan illustrating the location of the floor HFPs. 
centre of the lounge and bedroom, two above the joist (HFP2 \& HFP7) and two in-between the joists (HFP1 \& HFP6). The two sensors located in the kitchen were installed between the joists, one placed on the existing floor covering (HFP8) and the other onto the exposed floorboards (HFP9). Three sensors in the lounge (HFP3, HFP4 \& HFP5) were positioned 250, 750 and $1250 \mathrm{~mm}$ from the external wall in line with the airbrick on the East elevation, to ascertain whether proximity to the airbrick influenced the measurements. Sleeper walls in the ground floor void separated the measurement areas and each cluster of HFPs (HFP3, HFP4 \& HFP5), were all located in the same void section. However, the sleeper walls were of an open honeycomb construction, as shown in Figure 2, so airflow between the void sections was not restricted and was not expected to substantially influence the measured heat flux density.

HFPs were affixed to the ground floor, windows, external door and kitchen external walls using adhesive tape. To minimize the risk of damage to the wall and ceiling surfaces, the remaining HFPs were attached using a telescopic prop fitted with a spring loaded HFP holder, to ensure that the HFPs were in constant contact with the surface behind. For all HFPs, excluding those installed on the ground floor, a layer of thermal contact paste (Dow Corning 340 Heat Sink Compound) and cling film was installed between the HFP and the contact surface to minimize damage to the surfaces.

\section{Electric coheating test}

The electric coheating tests were undertaken in accordance with the Leeds Beckett Whole House Heat Loss Test Method (Johnston et al., 2013). It has been estimated that the uncertainty associated with the coheating test method is between \pm 8 and $10 \%$ (Jack et al., 2018); an error of $8 \%$ can be used in this research since the tests were undertaken under similar environmental and experimental conditions.

During the coheating tests, Eltek GC10 sensors (accuracy of $\pm 0.4^{\circ} \mathrm{C}$ ) monitored internal air temperature and proportional, integral, derivative (PID) temperature controllers ensured that the electric resistance heaters maintained the internal temperature at $\sim 22^{\circ} \mathrm{C}$. Air circulation fans ensured an even temperature distribution throughout the dwelling, thus minimizing any thermal stratification. Electrical power input was measured using Elster A100C kWh metres (accuracy of $\pm 1 \%$ ). A Vaisala WXT520 weather station installed on the gable wall collected external air temperature (accuracy of $\pm 0.3^{\circ} \mathrm{C}$ ) and wind speed data (accuracy of $\pm 3 \%$ at $10 \mathrm{~ms}^{-1}$ ). Solar insolation was also measured using a south facing vertically orientated Kipp and Zonen CMP 3 pyranometer (typical accuracy of $\pm 5 \%$ ). Energy introduced via solar gains were incorporated into the electric coheating analysis using linear regression, as described in the coheating test protocol (Johnston et al., 2013). Measurements were logged at 10-minute intervals using an Eltek Squirrel RX250AL data logger.

\section{Modelling thermal performance}

Stroma's RSAP+ software was used to generate before and after energy performance certificates (EPCs) for the case study dwelling and is an approved tool to deliver the Government's Reduced Standard Assessment Procedure (RdSAP) energy calculations. Two scenarios investigate how variations in the modelling inputs affect the model predictions. Scenario 1 applied default RdSAP assumptions to fabric U-values and thermal bridging. Scenario 2 was as Scenario 1, but with fabric Uvalues estimated by the BRE U-value calculator ${ }^{3}$ and thermal bridging values taken from Table $\mathrm{K} 1$ of the SAP manual (BRE, 2012). The HTC for both scenarios was then compared to the HTC measured in situ during the electric coheating test.

\section{Results and discussion}

\section{Airtightness and leakage identification}

For the pre-retrofit test, an Energy Conservatory Duct Blaster and a DG700 pressure/flow gauge were used to measure the airtightness of the case study dwelling. However, due to the poor air tightness of the dwelling it was only possible to achieve a maximum pressure difference of $40 \mathrm{~Pa}$ using this equipment. Given this, an alternative blower door, an Energy Conservatory Model 3 Blower Door with a DG700 pressure/flow gauge, was used for the post-retrofit test. However, both are calculated to a $50 \mathrm{~Pa}$ pressure differential the only difference being the size of the fan and the flow rates that can be achieved with the fan. The pressure and flow gauge and door fabric are identical and the same number of pressure and flow measurements were undertaken during both tests, under both pressurization and depressurization. The only difference between the tests is the range of pressures under which the tests were undertaken. By only undertaking the pre-retrofit pressurization tests with a maximum pressure differential of $40 \mathrm{~Pa}$, as opposed to greater than $50 \mathrm{~Pa}$, this should have minimal impact on the test results and any potential difference would be less than the level of uncertainty associated with the test method. The reason for undertaking the pre retrofits at lower pressure was because at higher pressures the increased inductive 
Table 1 . Pressurization test results.

\begin{tabular}{lcc}
\hline & Pre-retrofit & Post-retrofit \\
\hline Mean air permeability $\left(\mathrm{m}^{3} /\left(\mathrm{h} . \mathrm{m}^{2}\right) @ 50 \mathrm{~Pa}\right)$ & 18.3 & 11.2 \\
Mean air change rate $\left(\mathrm{ach}^{-1} @ 50 \mathrm{~Pa}\right)$ & 27.1 & 16.6 \\
Mean air change rate $\left(\mathrm{ach}^{-1}\right.$ background) & 1.15 & 0.70 \\
\hline
\end{tabular}

load required for the fan was enough to trip the circuit breaker on the domestic consumer unit.

The results of the air pressurization tests are summarized in Table 1 and indicate that in the pre-retrofit dwelling, uncontrolled air leakage was twice that of the average UK dwelling, obtaining a mean air change rate of $27.1 \mathrm{~h}^{-1} @ 50 \mathrm{~Pa}$. This is also twice the average for dwellings in England of the same age as the case study dwelling, at around $13 \mathrm{~h}^{-1} @ 50 \mathrm{~Pa}$ (Stephen, 1998, 2000). The natural average annual infiltration rate was approximated to be $1.15 \mathrm{~h}^{-1}$ pre- and $0.70 \mathrm{~h}^{-1}$ post-retrofit (using Sherman's ratio and based upon two sides of the dwelling being classed as sheltered).

Thermal imaging surveys were conducted prior to the pressurization tests under natural conditions and under a period of depressurization. It was therefore possible to distinguish infiltration under an induced negative pressure differential from issues caused by other anomalies, such as thermal bridging, transient effects or other surface effects. Pre-retrofit air leakage identification, using thermography, revealed substantial air leakage around the floor perimeter, through floorboard joints, around trickle vents and at service penetrations through the external wall. A number of these areas of air leakage are illustrated in the thermographs contained within Figures 4-6, respectively.

Post-retrofit air leakage reduced by just over $10 \mathrm{~h}^{-1} @$ $50 \mathrm{~Pa}$, from $27.1 \mathrm{~h}^{-1} @ 50 \mathrm{~Pa}$ to $16.6 \mathrm{~h}^{-1} @ 50 \mathrm{~Pa}$, representing a reduction of almost $40 \%$. The order of magnitude of the savings observed is well in excess of the measurement uncertainty associated with undertaking pressurization tests, or any additional uncertainty associated with using different measurement equipment between the tests and measuring the pre-retrofit airtightness at a maximum differential pressure of $40 \mathrm{~Pa}$.

Despite observing reduction in infiltration through the ground floor (see Figure 7), poor air tightness was still observed around trickle vents and also at external wall penetrations. It is not possible to identify how much of the observed reduction in infiltration could be attributed to the ground floor insulation compared to the ancillary sealing around service penetrations, since both were conducted in one staged retrofit, as in accordance with the product specification. However, only a marginal change in the airflow exponent was observed pre- and post-retrofit, indicating that the nature of the air leakage has not changed substantially between the tests.

It is important to note that the floor covering had already been removed for both the pre- and post-retrofit tests. Consequently, the air leakage reductions recorded are likely to be greater than that achieved in dwellings with existing floor coverings. It is also not possible to extrapolate these airtightness findings to the broader housing stock, which generally has lower levels of air infiltration (Stephen, 1998, 2000). Work undertaken by Stephen (1998) revealed that the proportion of whole dwelling air leakage attributable to suspended timber ground floors and additional sealing around ground floor service penetrations with no floor covering could be significant; ranging from $3.5 \%$ to $25.4 \%$, with a mean of $11.5 \%$.

The results indicate that in dwellings with poor airtightness, additional heat loss savings may be achieved by retrofitting suspended timber ground floor insulation, particularly if it is combined with ancillary sealing around ground floor service penetrations.

\section{Heat flux measurements pre- and post-retrofit}

The range of in situ U-values observed for all the other building elements is shown in Table 2. Values with an
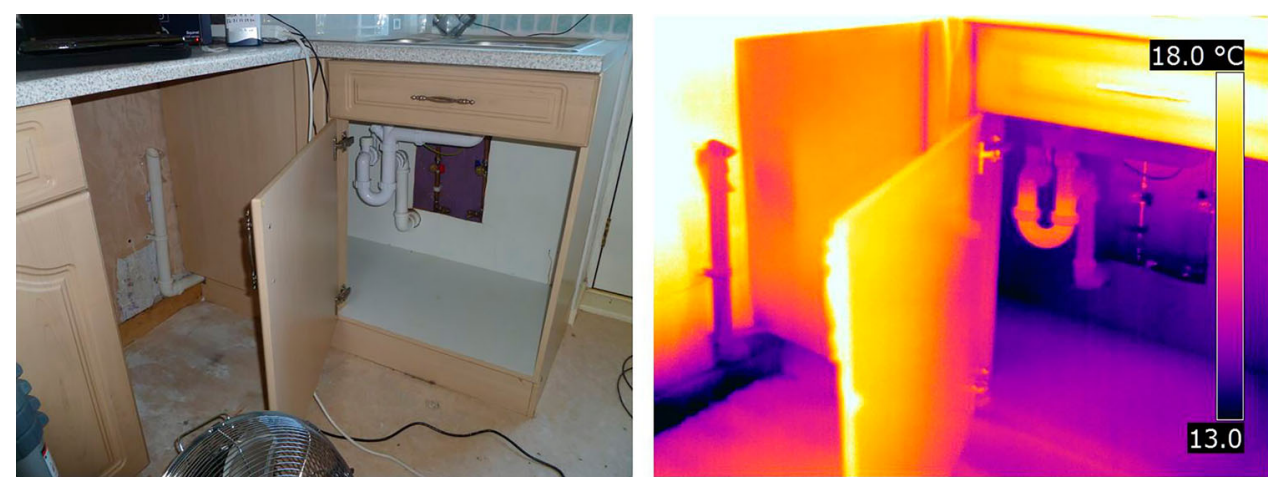

Figure 4 . Infiltration around service penetrations through the ground floor. 

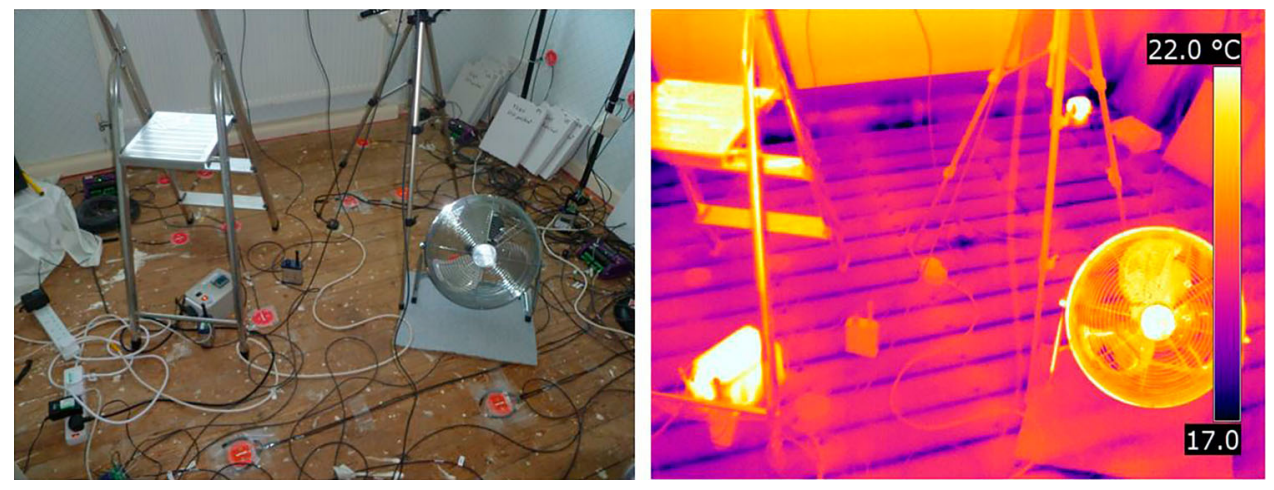

Figure $\mathbf{5}$. Infiltration through the ground floor.
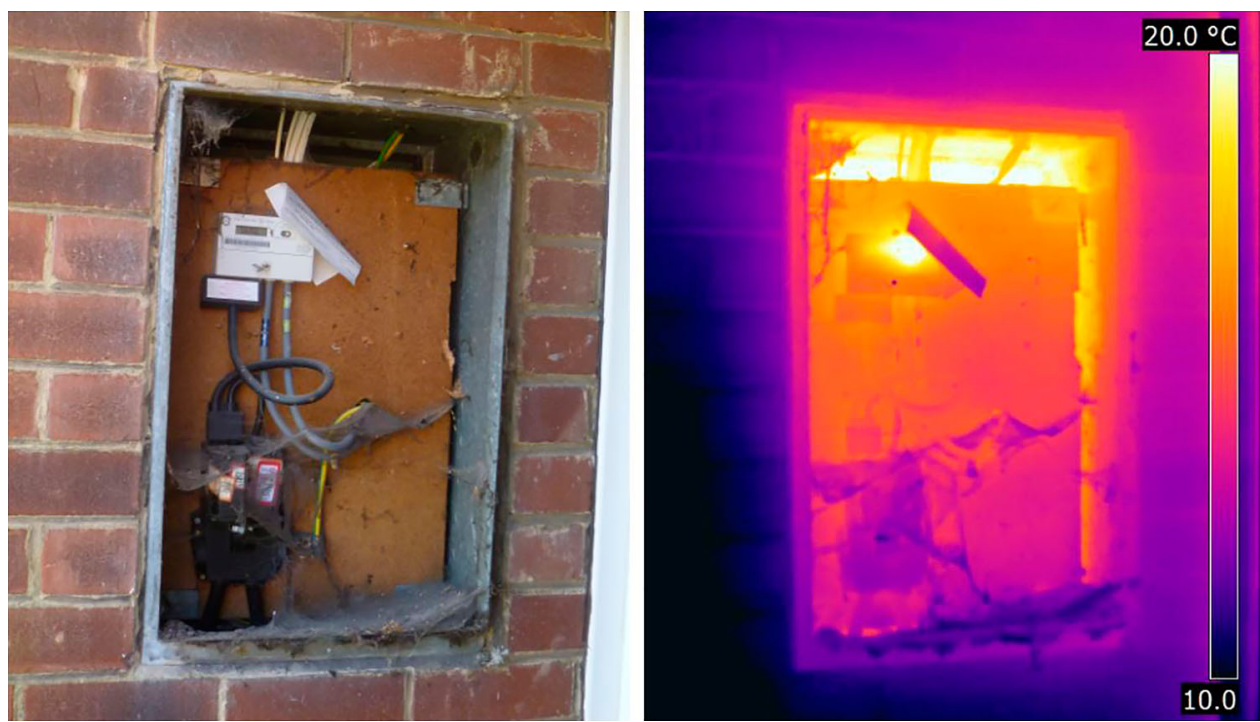

Figure 6 . Exfiltration through unsealed electricity metre open to interior of dwelling.

' $\mathrm{n} / \mathrm{a}$ ' indicate that the analysed data does not comply with the average method contained within ISO 98691:2014. These measurements confirm there was no substantial change (all differences are within margin the experimental error) in any of the building elements. In addition, no significant change was observed in the heat flux measured through the party walls pre- and post-retrofit. This is especially important, as there was no control over the conditions in the neighbouring property. These findings indicate that any changes measured in the HTC pre- and post-retrofit can be attributed to the application of the suspended timber ground floor insulation.

Also shown in Table 2 are the assumed U-values of the building fabric according to RdSAP and the BRE U-value calculator. While the external wall, party wall, windows and door appeared to be similar, the predicted $\mathrm{U}$-values for the suspended timber ground floor and ceiling varied. Additionally, the predicted U-values for all the elements differed from the measured in situ U-values.
This prediction modelling gap (Marshall et al., 2017) has implications for suspended timber ground floor retrofits and is discussed later.

Suspended timber ground floor in situ $\mathrm{U}$-values were derived from heat flux measurements (HFPs 1-9) to identify the change following the retrofit. It also enabled a comparison to be made between the $\mathrm{U}$-values specified by the insulation manufacturer, those contained within RdSAP and the measured in situ U-values. A summary of the average in situ $\mathrm{U}$-value measurements is provided within Table 3.

A range of performance was observed in the first HFP array (1-9) across the floor. On inspection of the HFPs, there was some uncertainty as to the extent to which HFP3 maintained contact with the suspended timber ground floor surface throughout the tests. This HFP was located near to an airbrick and close to the joist and external wall intersection. This location not only made the application of the suspended timber ground floor insulation more difficult but could have resulted in the thickness of 

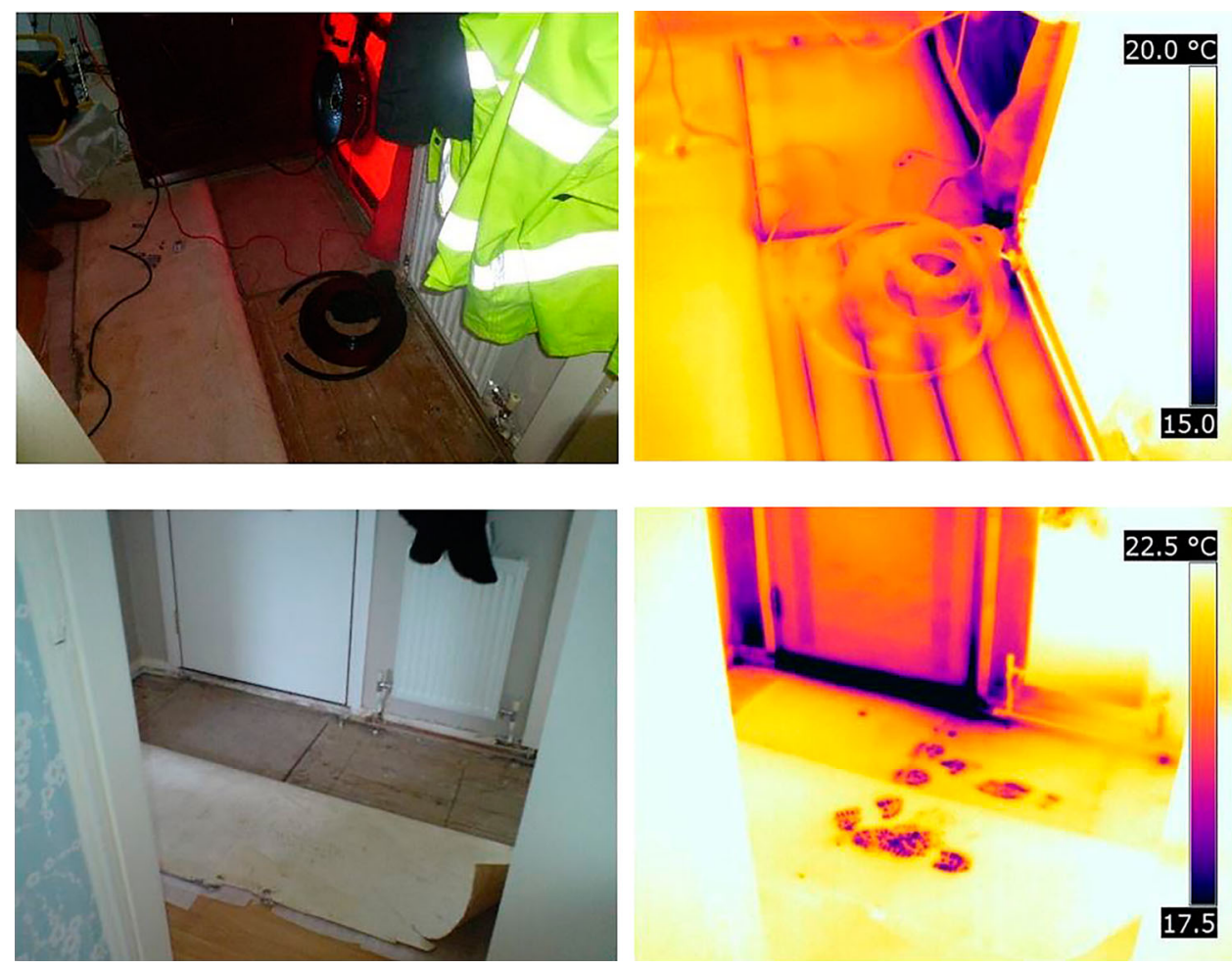

Figure 7 . Infiltration through hallway floor pre-retrofit (top) and post-retrofit (bottom).

the suspended timber ground floor insulation being compromised. However, the exact reason for this result was not possible to determine using the non-destructive testing methods available to the research team during the test periods. With respect to HFP9, a separate access tunnel was required for services below HFP9, meaning that the thickness of the insulation applied may have also been reduced in this area. The implications of this are that if insulation cannot be applied homogenously to the suspended timber ground floor, then there will be variations in the performance of the insulation. Consequently, the results obtained for HFP3 and HFP9 post-retrofit have been removed from the analysis, as they have been regarded as outliers.

Thus, the in situ $\mathrm{U}$-values ranging from between 0.95 $\pm 0.13-1.26 \pm 0.18 \mathrm{~W} / \mathrm{m}^{2} \mathrm{~K}$, pre- retrofit, and $0.11 \pm$ $0.02-0.32 \pm 0.04 \mathrm{~W} / \mathrm{m}^{2} \mathrm{~K}$ post-retrofit, in line with the $0.20 \mathrm{~W} / \mathrm{m}^{2} \mathrm{~K}$ target. The improvement in $\mathrm{U}$-value ranged from $0.71 \pm 0.19 \mathrm{~W} / \mathrm{m}^{2} \mathrm{~K}$ to $1.13 \pm 0.19 \mathrm{~W} / \mathrm{m}^{2} \mathrm{~K}$, equating to a percentage improvement of $69 \%$ to $91 \%$. The average improvement was $0.89 \mathrm{~W} / \mathrm{m}^{2} \mathrm{~K}(80 \%)$.

In all instances the in situ $\mathrm{U}$-values measured above the joists were better than that measured between joists prior to the retrofit, clearly the joist had an insulating effect. Postretrofit the opposite was observed because less insulation could be applied directly below the joist (only $30 \mathrm{~mm}$ compared to $130 \mathrm{~mm}$ ). However, the extent to which the HFPs located directly above the joists have greater heat flow in comparison to their neighbouring HFPs between the joists was not consistent, indicating that there may be some variation in the applied insulation thickness.

Other variability was observed in the pre-retrofit in situ U-values. An increase in in situ U-value was observed the greater the distance from the airbrick located on the east elevation (HFP3, 4 and 5). This result appears to be counter-intuitive. Conversely, post-retrofit, the pattern was reversed. Additionally, there is some uncertainty over the contact maintained by HFP3 throughout the test, although this would not explain the result obtained pre-retrofit at HFP location HFP4.

\section{Electric coheating test results}

An analysis of the external environmental data that was monitored during the testing period was undertaken preand post-retrofit (see Table 4). This analysis confirmed that there was only a marginal difference in the test conditions experienced pre- and post-retrofit. This indicates that any differences in building fabric performance measured are likely to be attributable to the ground floor insulation retrofit, rather than differences in environmental conditions between the two test phases.

The solar corrected HTC obtained from the electric coheating tests is illustrated in Table 5 and Figure 8 for which a maximum total uncertainty in the measurement of $\pm 8 \%$ has been assumed (Jack et al., 2018). 
Table 2 . Building elemental point U-value measurements pre- and post-retrofit.

\begin{tabular}{|c|c|c|c|c|c|}
\hline & $\begin{array}{l}\text { RdSAP U-value } \\
\left(\mathrm{W} / \mathrm{m}^{2} \mathrm{~K}\right)\end{array}$ & $\begin{array}{l}\text { BRE calculator U- } \\
\text { value }\left(\mathrm{W} / \mathrm{m}^{2} \mathrm{~K}\right)\end{array}$ & $\begin{array}{c}\text { Measured range in U-value } \\
\text { pre-retrofit }\left(\mathrm{W} / \mathrm{m}^{2} \mathrm{~K}\right)\end{array}$ & $\begin{array}{c}\text { Measured range in U-value } \\
\text { post-retrofit }\left(\mathrm{W} / \mathrm{m}^{2} \mathrm{~K}\right)\end{array}$ & $\begin{array}{c}\text { Change in measured } \mathrm{U}- \\
\text { value }\left(\mathrm{W} / \mathrm{m}^{2} \mathrm{~K}\right)\end{array}$ \\
\hline Floor & 1.2 & 0.7 & $\begin{array}{l}0.95 \pm 0.13 \text { to } \\
1.26 \pm 0.18\end{array}$ & $\begin{array}{l}0.11 \pm 0.02 \text { to } \\
0.32 \pm 0.04\end{array}$ & \\
\hline Lounge Window & 2.8 & 2.8 & $n / a$ & $1.01 \pm 0.14$ & $\mathrm{n} / \mathrm{a}$ \\
\hline Bedroom Window & 2.8 & 2.8 & $0.93 \pm 0.13$ & $1.01 \pm 0.14$ & -0.08 \\
\hline Kitchen Door & 2.1 & 2.1 & $1.20 \pm 0.17$ & $1.15 \pm 0.16$ & 0.05 \\
\hline $\begin{array}{l}\text { Lounge Ceiling } \\
\text { Edge }\end{array}$ & 0.2 & 0.4 & $0.84 \pm 0.12$ & $\mathrm{n} / \mathrm{a}$ & $\mathrm{n} / \mathrm{a}$ \\
\hline $\begin{array}{l}\text { Lounge Ceiling } \\
\text { Centre }\end{array}$ & 0.2 & 0.4 & $0.16 \pm 0.02$ & $0.14 \pm 0.02$ & 0.02 \\
\hline $\begin{array}{l}\text { Bedroom Ceiling } \\
\text { Edge }\end{array}$ & 0.2 & 0.4 & $1.97 \pm 0.28$ & $1.99 \pm 0.28$ & -0.02 \\
\hline $\begin{array}{l}\text { Bedroom Ceiling } \\
\text { Centre }\end{array}$ & 0.2 & 0.4 & $0.04 \pm 0.01$ & $0.05 \pm 0.01$ & -0.01 \\
\hline $\begin{array}{l}\text { Kitchen West } \\
\text { External Wall }\end{array}$ & 0.5 & 0.5 & $0.89 \pm 0.12$ & $0.80 \pm 0.11$ & 0.09 \\
\hline $\begin{array}{l}\text { Kitchen North } \\
\text { External Wall } 1\end{array}$ & 0.5 & 0.5 & $n / a$ & $0.97 \pm 0.14$ & $\mathrm{n} / \mathrm{a}$ \\
\hline $\begin{array}{l}\text { Kitchen North } \\
\text { External Wall } 2\end{array}$ & 0.5 & 0.5 & $0.97 \pm 0.14$ & $0.97 \pm 0.14$ & 0.00 \\
\hline $\begin{array}{l}\text { Bathroom East } \\
\text { External Wall }\end{array}$ & 0.5 & 0.5 & $0.98 \pm 0.14$ & $0.91 \pm 0.13$ & 0.07 \\
\hline
\end{tabular}

The addition of floor insulation has resulted in the aggregate HTC of the case study dwelling reducing from $178 \pm 14 \mathrm{~W} / \mathrm{K}$ pre-retrofit, to $135 \pm 11 \mathrm{~W} / \mathrm{K}$ post-retrofit. A separate assessment of the standard errors associated with the multiple linear regression analysis only was found to be $\pm 5 \mathrm{~W} / \mathrm{K}$ (adjusted $r^{2}=$ 0.95 ) pre- and $\pm 6 \mathrm{~W} / \mathrm{K}$ (adjusted $r^{2}=0.87$ ). The measured whole dwelling HTC can be further disaggregated into an approximated fabric and background ventilation heat loss by applying Sherman's ratio; the $\mathrm{N}_{50} / 20$ assumption (Sherman, 1987), to the pre- and post-retrofit air leakage rates. This result in an approximated reduction in the HTC attributed to background ventilation of $18 \mathrm{~W} / \mathrm{K}$.

The overall measured reduction in HTC of $43 \pm$ $18 \mathrm{~W} / \mathrm{K}$ represents a $24 \%$ improvement in the HTC attributable to the ground floor retrofit. This is substantially higher than the $13 \mathrm{~W} / \mathrm{K}(11 \%)$ reduction in HTC previously found by Farmer et al. (2017). In addition, the improvement in airtightness observed by Farmer et al. (2017) was only $8 \%$, in comparison to $40 \%$ for this case study. Additionally, their retrofit took place on a two-storey end-terraced dwelling in which the ground floor represented a much smaller proportion of the overall heat loss area. This indicates the benefit of ground floor retrofits may be related to the dwelling form and condition.

This case study dwelling was only half as airtight as the average UK house, had floor coverings removed and had a large ground floor area to heat loss area ratio, thus savings are likely to be lower for other housing types. It is also worth noting that the predicted HTC

Table 3 . Summary of the average calculated in situ U-value measurements.

\begin{tabular}{|c|c|c|c|c|}
\hline & $\begin{array}{c}\text { Pre-retrofit } \\
\text { U-value } \\
\text { (W/m K) }\end{array}$ & $\begin{array}{c}\text { Post-retrofit } \\
\text { U-value } \\
\left(\mathrm{W} / \mathrm{m}^{2} \mathrm{~K}\right)\end{array}$ & Measured reduction in $\mathrm{U}$-value & $\%$ Improvement \\
\hline HFP1 - Living room between joist & $1.19 \pm 0.17$ & $0.11 \pm 0.02$ & 1.08 & $91 \%$ \\
\hline HFP2 - Living room above joist & $0.95 \pm 0.13$ & $0.18 \pm 0.03$ & 0.77 & $81 \%$ \\
\hline HFP3 - Living room & $0.82 \pm 0.11$ & $0.41 \pm 0.06$ & 0.41 & $50 \%$ \\
\hline HFP4 - Living room & $1.00 \pm 0.14$ & $0.27 \pm 0.04$ & 0.73 & $73 \%$ \\
\hline HFP5 - Living room & $1.26 \pm 0.18$ & $0.13 \pm 0.02$ & 1.13 & $90 \%$ \\
\hline HFP6 - Bedroom between joist on floor covering & $1.15 \pm 0.16$ & $0.18 \pm 0.03$ & 0.97 & $84 \%$ \\
\hline HFP7 - Bedroom above joist on floor covering & $1.03 \pm 0.14$ & $0.32 \pm 0.04$ & 0.71 & $69 \%$ \\
\hline HFP8 - Kitchen between joist on floor covering & $1.04 \pm 0.15$ & $0.28 \pm 0.04$ & 0.76 & $73 \%$ \\
\hline HFP9 - Kitchen between joist & $1.23 \pm 0.17$ & $0.87 \pm 0.12$ & 0.36 & $29 \%$ \\
\hline
\end{tabular}


Table 4. Test conditions experienced during the pre- and postretrofit.

\begin{tabular}{lcc}
\hline Variable & $\begin{array}{c}\text { Pre- } \\
\text { retrofit }\end{array}$ & $\begin{array}{c}\text { Post- } \\
\text { retrofit }\end{array}$ \\
\hline $\begin{array}{l}\text { Mean daily temperature difference between case } \\
\text { study dwelling and external environment }\end{array}$ & $14.06^{\circ} \mathrm{C}$ & $14.36^{\circ} \mathrm{C}$ \\
$\begin{array}{l}\text { Mean daily temperature difference between case } \\
\text { study dwelling and adjacent dwelling }\end{array}$ & $-0.11^{\circ} \mathrm{C}$ & $-0.53^{\circ} \mathrm{C}$ \\
Mean daily wind speed & $2.05 \mathrm{~m} / \mathrm{s}$ & $1.82 \mathrm{~m} / \mathrm{s}$ \\
\hline
\end{tabular}

reduction from the EPC SAP model in Figure 8 was 23\%, which is very close to the total $24 \%$ improvement measured in situ. However, given that the model assumes no ventilation improvements, this result is somewhat unexpected and is discussed further below.

\section{Deriving an improvement in U-value from an aggregate HTC}

It is possible to approximate the effective improvement in the ground floor U-value achieved by the application of the ground floor insulation by dividing the approximated reduction in fabric heat loss, (see Table 5), by the ground floor area of $43.86 \mathrm{~m}^{2}$. This results in an effective reduction in the ground floor $\mathrm{U}$-value of $0.55 \mathrm{~W} / \mathrm{m}^{2} \mathrm{~K}$. This can be considered a more robust estimate of the actual reduction in heat loss since it accounts for the complexities of heat transfer in a dynamic system such as a house, specifically thermal bridging. It is important to note that this is a smaller reduction in Uvalue than was estimated by the spot heat flux values, which indicated an average improvement of $0.89 \mathrm{~W} /$ $\mathrm{m}^{2} \mathrm{~K}$. If HFP3 and HFP9 are included in the analysis, then the average improvement in $\mathrm{U}$-value only reduces to $0.77 \mathrm{~W} / \mathrm{m}^{2} \mathrm{~K}$. However, these measurements were used indicatively to illustrate the extent of change in conductive heat loss. It is not clear if measuring heat flux density in more locations may have substantially changed this result or achieved parity with the U-value derived via the aggregated approach. This could form the basis for future research.

\section{Modelled and measured heat loss}

RdSAP is the government's modelling software on which EPCs are based (BRE, 2012). This provides a simplified and standardized estimate of energy used in homes, which is useful in informing and tracking policy interventions at a national scale, however, it also has some challenging limitations. For example, unlike in the full SAP used for new builds, changes to the default ventilation rates cannot be made in RdSAP, this is a problem as it also assumes that fabric retrofits only affect conductive heat loss, meaning any convective heat loss reductions are ignored. Additionally, as illustrated in Table 2, the assumed U-values contained within RdSAP often do not reflect those observed on-site (Marshall et al., 2017). Thus, the benefits of ground floor insulation modelled in RdSAP, may differ from the actual benefits received by the household.

Table 6 illustrates the modelled HTC for the building post-retrofit under two scenarios (Scenario 1 and 2), as well as the measured HTC obtained from the electric coheating test. Scenario 1 represents the outputs from the initial RdSAP model using default values (Appendix $\mathrm{S})$, including a standard $y$-value of $0.15 \mathrm{~W} / \mathrm{m}^{2} \mathrm{~K}$ to represent thermal bridging. Scenario 2 uses the U-values predicted by the BRE U-value calculator, to provide a more accurate model, as it is recognized that the Uvalue defaults incorporated within RdSAP are often not reflective of the performance of the fabric in the field (Marshall et al., 2017). Both of these figures are compared with the HTCs measured by the electric coheating test in Table 6.

Scenario 1 predicts a similar percentage reduction in whole house HTC to that measured using the electric coheating test. However, since it does not account for changes in background ventilation heat loss, Scenario 1 overestimates the fabric heat loss reduction because the pre-retrofit wall U-value was unrealistic. Scenario 2 makes a better prediction of the fabric heat losses, since it is based on more realistic fabric U-value assumptions, although again it does not account for reductions in background ventilation heat loss. Therefore, Scenario 2 under predicts the benefit of the retrofit. These findings highlight the difficulties associated with using steadystate thermal models to predict the impact that thermal upgrades may have on a dwelling. Specifically, it indicated that using default assumptions for the fabric and ventilation heat loss may result in unrepresentative estimates of the benefits of retrofits. This is relevant for

Table 5 . Whole house heat losses.

\begin{tabular}{lccc}
\hline & $\begin{array}{c}\text { Pre-retrofit } \\
\text { (W/K) }\end{array}$ & $\begin{array}{c}\text { Post-retrofit } \\
\text { (W/K) }\end{array}$ & $\begin{array}{c}\text { Reduction in HTC } \\
\text { (W/K) }\end{array}$ \\
\hline Total measured heat loss & $177.7 \pm 14.2$ & $135.3 \pm 10.8$ & $42.2 \pm 25.0$ \\
Approximated background ventilation heat loss & 46.9 & 28.7 & 18.2 \\
Approximated fabric heat loss & 130.8 & 106.6 & 24.2 \\
\hline
\end{tabular}




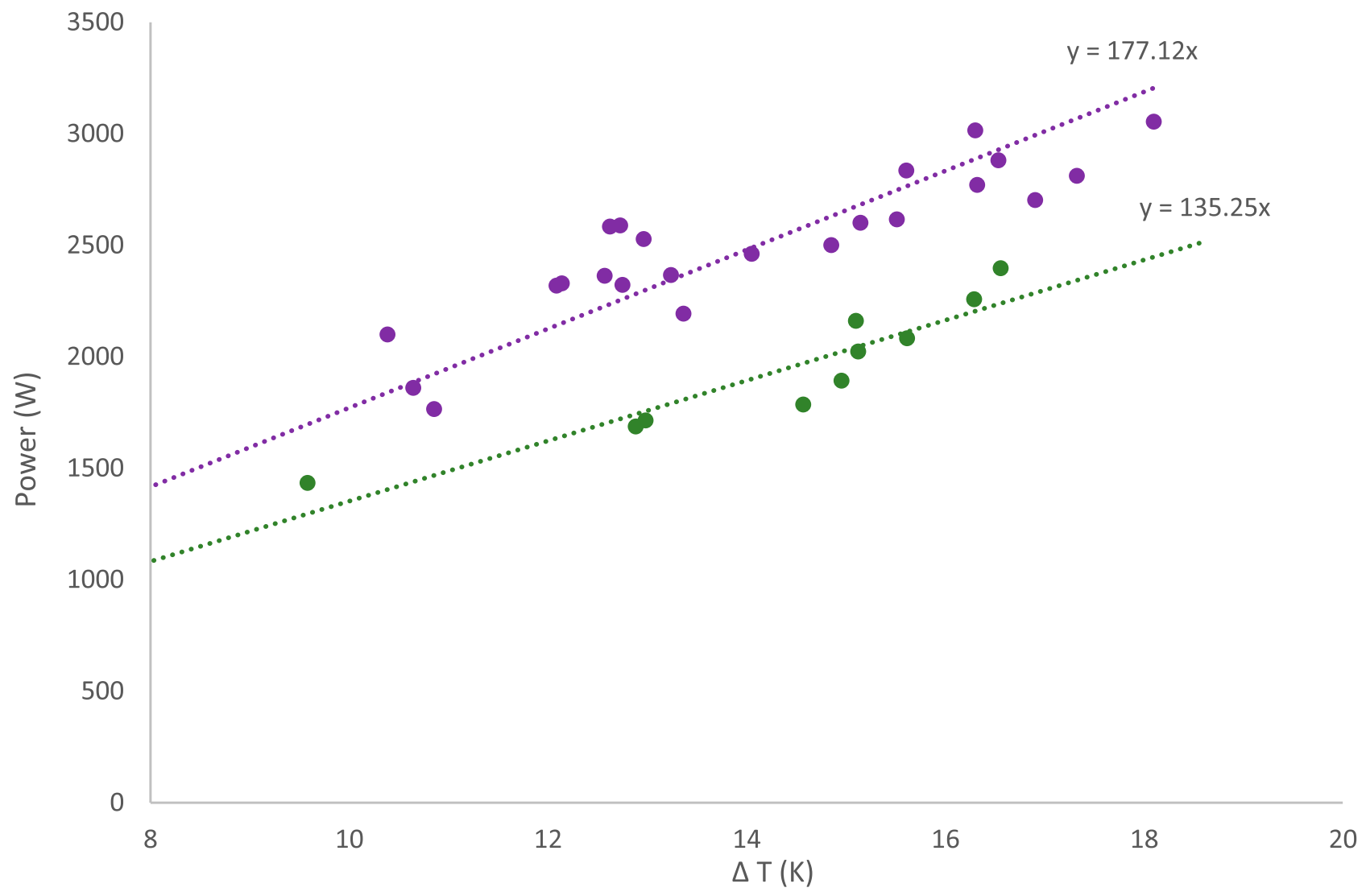

Figure 8. Whole house HTC for dwelling pre- and post-retrofit.

current policy, since EPCs are the basis of financial payments to energy companies. Greater flexibility around inputting more realistic assumed fabric U-values, along with being able to input measured before and after infiltration rates in RdSAP, could improve the accuracy of the predicted savings.

EPC is a recognized certification for householders and they are a standardized assessment procedure. They provide useful output metrics for householders, including fuel bill estimates and an aggregate dwelling energy efficiency rating from $A$ to $G$. The outputs associated with the two EPCs produced in this project (Scenario 1 and Scenario 2), are illustrated in Table 7.

In both Scenarios the suspended timber floor retrofit failed to improve the bungalow's EPC rating of D. In the context of Minimum Energy Efficiency Standards (MEES) this is worth highlighting because improving the EPC band is the main requirement. This indicates single measure retrofits like floor insulation may not be able to achieve future policy goals (BEIS, 2018).

The improvements made by retrofits can be described via a range of metrics; reductions in HTC (W/K), reductions in space heating energy use $(\mathrm{kWh})$, annual fuel bill savings, GHG reductions, SAP point reductions or EPC bands. Table 7, illustrates metrics provided by the EPC, Savings to fuel bills may be the most pertinent metric for householders and these were estimated by RdSAP to range from $£ 171$ per year to $£ 309$ per year. Using this information, along with the BEIS costs estimates for suspended timber ground floor insulation of between $£ 87$ and $£ 208$ per $\mathrm{m}^{2}$ the retrofit for this case study dwelling would have a payback period of somewhere between 11 and 48 years.

The findings also highlight that the Government's RdSAP tool, which generates EPCs to evaluate the success of retrofits, is incapable of capturing convective heat loss reductions resulting from fabric insulation retrofits. It also indicates that the default U-values used in RdSAP may not reflect measured in situ U-values, and so EPCs are unlikely to realistically predict the benefits of retrofits. The implications of this are that thousands of retrofits may have received unrepresentative EPC scores. It is important that homes have correct EPC scores since this can determine their access to government funding (BEIS, 2018), influence house prices (BEIS, 2013; Fuerst, McAllister, Nanda, \& Wyatt, 2016), and are the means by which Government evaluates policy success.

\section{Conclusion}

The findings indicate that suspended timber ground floor insulation retrofits could reduce domestic space 
Table 6 . rdSAP input data and calculated heat loss pre- and post-retrofit.

\begin{tabular}{lccc}
\hline & $\begin{array}{c}\text { Scenario } 1 \\
\text { (W/K) }\end{array}$ & $\begin{array}{c}\text { Scenario 2 } \\
\text { (W/K) }\end{array}$ & $\begin{array}{c}\text { Measured } \\
\text { approximated HTC } \\
\text { (W/K) }\end{array}$ \\
\hline $\begin{array}{c}\text { Pre-retrofit fabric heat } \\
\text { loss (including } \\
\text { thermal bridging) }\end{array}$ & 140.6 & 132.9 & 137.0 \\
$\begin{array}{c}\text { Pre-retrofit ventilation } \\
\text { heat loss }\end{array}$ & 30.1 & 30.1 & 40.7 \\
$\begin{array}{c}\text { Pre-retrofit whole house } \\
\text { heat loss }\end{array}$ & 170.7 & 163 & 177.7 \\
$\begin{array}{c}\text { Post-retrofit fabric heat } \\
\text { loss (including } \\
\text { thermal bridging) }\end{array}$ & 101.0 & 111.3 & 110.4 \\
$\begin{array}{c}\text { Post-retrofit ventilation } \\
\text { heat loss }\end{array}$ & 30.1 & 30.1 & \\
$\begin{array}{c}\text { Post-retrofit whole } \\
\text { house heat loss }\end{array}$ & 131.0 & 141.4 & 27.2 \\
$\begin{array}{c}\text { Proportional reduction } \\
\text { in whole house HTC } \\
\text { from retrofit }\end{array}$ & $23 \%$ & $14 \%$ & 137.6 \\
\hline
\end{tabular}

heating energy demand. For this case study bungalow, which had poor levels of airtightness and a large floor area to heat loss area ratio, the HTC decreased by $24 \%$ via reductions in both fabric and ventilation heat losses. This suggests that suspended timber ground floor retrofits have the potential to contribute to national carbon reduction policy, and by reducing draughts, could also result in improvements to the thermal comfort experienced by the occupants. However, further research is required to investigate the practicalities, costs and potential $\mathrm{CO}_{2}$ emission reductions that could be achieved by increasing the adopting suspended timber ground floor retrofits, as well as understanding how these retrofits are likely to affect thermal comfort and moisture risks in dwellings.

A comparison of the two separate measurement approaches to evaluate the suspended timber ground floor retrofit suggests that the adoption of an aggregate measurement method, in this case an electric coheating test, may produce a more reliable evaluation of the thermal benefits of a fabric retrofit, and should be adopted where practical. Aggregate methods are not only capable of

Table 7 . Predicted savings of floor retrofit calculated by EPC (rdSAP).

\begin{tabular}{lcc}
\hline & Scenario 1 & Scenario 2 \\
\hline Reduction in HTC (W/K) & $39.2(23 \%)$ & $21.4(14 \%)$ \\
$\begin{array}{l}\text { Reduction in annual space heating energy } \\
\text { use }(\mathrm{kWh})\end{array}$ & $\begin{array}{c}1826 \mathrm{kWh} \\
(26 \%)\end{array}$ & $\begin{array}{c}1006 \mathrm{kWh} \\
(16 \%)\end{array}$ \\
$\begin{array}{l}\text { Reduction in fuel bills (heat and } \\
\text { electricity) (£) }\end{array}$ & $£ 309(16 \%)$ & $£ 171(9 \%)$ \\
$\begin{array}{l}\text { Improvement in SAP score (out of 100) } \\
\text { EPC dwelling rating }\end{array}$ & 6 & 3 \\
\hline
\end{tabular}

accounting for the heterogeneity of heat flow that occurs across the ground floor surface, but they also account for thermal bridging and any changes in infiltration heat loss. Consequently, they can overcome the main limitations associated with adopting a disaggregated measurement approach. This finding challenges the current practice of using disaggregated measurement approaches, such as point heat flux density measurements and air pressurization tests, to assess the impacts of fabric insulation retrofits. Disaggregated methods, such as spot heat flux density measurements and air pressurization tests, are however, currently, more widely adopted and are also used to inform government policy (BRE, 2016). This may be, in part, because aggregate methods, such as the electric coheating test, are time-consuming and are often impractical to undertake commercially. They are only reliable when undertaken during the space heating season and require the property to be unoccupied throughout the test period, which is not always practical. Consequently, developing alternative aggregate measurement approaches that are capable of overcoming a number of these limitations should be the focus of future research.

\section{Notes}

1. connect.innovateuk.org/web/building-performanceevaluation

2. www.q-bot.co

3. http://projects.bre.co.uk/uvalues/

\section{Disclosure statement}

No potential conflict of interest was reported by the authors.

\section{Funding}

This work was supported by Qbot.

\section{References}

Alexander, D. K., \& Jenkins, H. G. (2015). The validity and reliability of co-heating tests made on highly insulated dwellings. Energy Procedia, 78, 1732-1737. doi:10.1016/j. egypro.2015.11.282

ATTMA. (2016). Technical Standard L1. Measuring air permeability of building envelopes (Dwellings). Retrieved 2017 from https:/www.attma.org/wp-content/uploads/ 2016/09/ATTMA-TSL1-Issue-3-Rev-0-2016.09.09.pdf

Bauwens, \& Roels. (2014). Co-heating test: A state-of-the-art. Energy and Buildings, 82, 163-172. doi:10.1016/j.enbuild. 2014.04.039

Bauwens, Standaert, \& Delcuve. (2012, 10-11 September 2012). Reliability of co-heating measurements. Proceedings of BSO12: IBPSA-England first building simulation and optimisation conference, Loughborough. 
BEIS. (2013). An investigation of the effect of EPC ratings on house prices. In Department for Business EaIS. London.

BEIS. (2017a). The government response to the ECO: Help to heat consultation. London: BEIS. Retrieved from https:// www.gov.uk/government/uploads/system/uploads/attachm ent_data/file/586260/ECO_Help_to_Heat_Government_re sponse_FINAL_26_Jan_17.pdf

BEIS. (2017b). Household energy efficiency headline release executive summary. London: Statistical Release: National Statistics.

BEIS. (2018). Domestic private rented sector minimum level of energy efficiency: summary of responses. London: Retrieved from https://assets.publishing.service.gov.uk/government/ uploads/system/uploads/attachment_data/file/729753/dom estic-rented-sector-minimum-level-energy-eficiency-respo nses.pdf

Blumstein, C., Krieg, B., Schipper, L., \& York, C. (1980). Overcoming social and institutional barriers to energy conservation. Energy, 5(4), 355-371. doi:10.1016/0360-5442 (80)90036-5

BRE. (2012). The government's standard assessment procedure for energy rating of dwellings 2012 edition. Garston: Watford.

BRE. (2014). Solid wall heat losses and the potential for energy saving, Literature review. London: Author.

BRE. (2016). Solid wall heat losses and the potential for energy saving, consequences for consideration to maximise SWI benefits: A route-map for change. London: BRE.

BSI. (2014). BS ISO 9869-1:2014: Thermal insulation - building elements - in situ measurement of thermal resistance and thermal transmittance. Part 1: Heat flow meter method. London: The British Standards Institution.

CCC. (2016). Meeting Carbon Budgets, 2016 Progress Report to Parliament. https://www.theccc.org.uk/wp-content/uploads/2 016/06/2016-CCC-Progress-Report-Executive-Summary.pdf

Cheng, Y., Lin, Z., \& Fong, A. M. L. (2015). Effects of temperature and supply airflow rate on thermal comfort in a stratum-ventilated room. Building and Environment, 92, 269-277. doi:10.1016/j.buildenv.2015.04.036

CIBSE. (2000). Testing buildings for air leakage: CIBSE technical memoranda TM23. London: Author.

Climate Change Act C 27. (2008).

DCLG. (2016). English Housing Survey, Headline Report, 201516. London.

Elsharkawy, H., \& Rutherford, P. (2018). Energy-efficient retrofit of social housing in the UK: Lessons learned from a community energy saving programme (CESP) in Nottingham. Energy and Buildings, 172, 295-306. doi:10. 1016/j.enbuild.2018.04.067

EST. (2003). Good Practice Guide 171: Domestic energy efficiency primer. London: Author.

EST. (2017). Cavity wall. Retrieved 2017 from http://www. energysavingtrust.org.uk/home-insulation/cavity-wall

Everett. (1985). Rapid thermal calibration of houses Technical Report ERG 055 for the Science and Engineering Research Council. Milton Keynes: Energy Research Group.

Farmer, D., Gorse, C., Swan, W., Fitton, R., Brooke-Peat, M., Miles-Shenton, D., \& Johnston, D. (2017). Measuring thermal performance in steady-state conditions at each stage of a full fabric retrofit to a solid wall dwelling. Energy and Buildings, 156(Supplement C), 404-414. doi:10.1016/j. enbuild.2017.09.086
Fuerst, F., McAllister, P., Nanda, A., \& Wyatt, P. (2016). Energy performance ratings and house prices in Wales: An empirical study. Energy Policy 92, 20-33.

Fylan, F., Glew, D., Smith, M., Johnston, D., Brooke-Peat, M., Miles-Shenton, D., ... Gorse, C. (2016). Reflections on retrofits: Overcoming barriers to energy efficiency among the fuel poor in the United Kingdom. Energy Research of Social Science, 21, 190-198. doi:10.1016/j.erss.2016.08.002

Guerra-Santin, O., Tweed, C., Jenkins, H., \& Jiang, S. (2013). Monitoring the performance of low energy dwellings: Two UK case studies. Energy and Buildings, 64, 32-40. doi:10. 1016/j.enbuild.2013.04.002

Gupta, R., Gregg, M., Passmore, S., \& Stevens, G. (2015). Intent and outcomes from the retrofit for the future programme: Key lessons. Building Research and Information, 43(4), 435-451. doi:10.1080/09613218.2015.1024042

Hall, M. R., Casey, S. P., Loveday, D. L., \& Gillott, M. (2013). Analysis of UK domestic building retrofit scenarios based on the E.ON retrofit research house using energetic hygrothermics simulation - energy efficiency, indoor air quality, occupant comfort, and mould growth potential. Building and Environment, 70, 48-59. doi:10.1016/j.buildenv.2013. 08.015

Hamilton, I. G., Summerfield, A. J., Shipworth, D., Steadman, J. P., Oreszczyn, T., \& Lowe, R. J. (2016). Energy efficiency uptake and energy savings in English houses: A cohort study. Energy and Buildings, 118, 259-276. doi:10.1016/j. enbuild.2016.02.024

Harris, D,J, \& Dudek, S,JM. (1997). Heat losses from suspended timber floors. Laboratory experiments measuring heat losses through flooring utilizing a variety of insulation and ventilation rates to determine appropriate strategies for retrofitting insulation. Building Research \& Information, 25, 226-233.

Hens, H., Janssens, A., Depraetere, W., Carmeliet, J., \& Lecompte, J. (2007). Brick cavity walls: A performance analysis based on measurements and simulations. Journal of Building Physics, 31 (2), 95-124. doi:10.1177/1744259107082685

Holloway, M., Childs, P. R. N., \& Julia, M. (2016a). Folding mechanism for a remotely deployable robotic vehicle. Paper presented at the ISR 2016. 47th International Symposium on Robotics, Munich, Germany.

Holloway, M., Childs, P. R. N., \& Julia, M. (2016b). A robot for spray applied insulation in underfloor voids. Paper presented at the ISR 2016. 47th International Symposium on Robotics, Munic, Germany.

Hong, S. H., Oreszczyn, T., \& Ridley, I. (2006). The impact of energy efficient refurbishment on the space heating fuel consumption in English dwellings. Energy and Buildings, 38(10), 1171-1181. doi:10.1016/j.enbuild.2006.01.007

Innovate UK. (2016). Retrofit revealed the retrofit for the future projects - data analysis report. Swindon: Innovate UK.

Jack, R., Loveday, D., Allinson, D., \& Lomas, K. (2018). First evidence for the reliability of building co-heating tests. Building Research \& Information, 46(4), 383-401. doi:10. 1080/09613218.2017.1299523

Johnston, D., Miles-Shenton, D., Farmer, D., Wingfield, J., \& Bell, M. (2013). Whole house heat loss test method (coheating). Leeds: Leeds Beckett University.

Jones, R. V., Goodhew, S., \& de Wilde, P. (2016). Measured indoor temperatures, thermal comfort and overheating risk: Post-occupancy evaluation of low energy houses in 
the UK. Energy Procedia, 88, 714-720. doi:10.1016/j.egypro. 2016.06.049

Killip, G. (2005). Built fabric and building regulations, background material F, 40\% House Project. https://www.eci.ox. ac.uk/research/energy/downloads/40house/background_do c_f.pdf

Ma, Z., Cooper, P., Daly, D., \& Ledo, L. (2012). Existing building retrofits: Methodology and state-of-the-art. [Review]. Energy and Buildings, 55, 889-902. doi:10.1016/j.enbuild.2012.08.018

Marshall, A., Fitton, R., Swan, W., Farmer, D., Johnston, D., Benjaber, M., \& Ji, Y. (2017). Domestic building fabric performance: Closing the gap between the in situ measured and modelled performance. Energy and Buildings, 150, 307-317. doi:10.1016/j.enbuild.2017.06.028

Mott McDonald. (2013). Q-bot owner occupiers research. London: Mott McDonald.

NBS. (2014). The Building Regulations 2010 Approved Document L1A: Conservation of fuel and power in new dwellings. London: NBS.

NEF. (Undated). Insulating your home: Insulating your floor. Retrieved 2017 from http://www.nef.org.uk/knowledgehub/view/insulating-your-home

OFGEM. (2013a). The final report of the Carbon Emissions Reduction Target (CERT) 2008-2012.

OFGEM. (2013b). The final report of the Community Energy Saving Programme (CESP) 2009-2012. London.

OFGEM. (2015). Energy Companies Obligation Final Report.

OFGEM. (2017). Energy Company Obligation (ECO2t): Measures Table. London: Retrieved from https://www. ofgem.gov.uk/system/files/docs/2017/05/eco2t_measures_ table_-_may_2017-_v5.pdf

Palmer, J., \& Cooper, I. (2013). United Kingdom housing energy fact file. London: Cambridge Architectual Research.

Palmer, J., Livingstone, M., \& Adams, A. (2017). What does it cost to retrofit homes? Updating the cost assumptions for BEIS's energy efficiency modelling. London: CAR. Retrieved from https://assets.publishing.service.gov.uk/government/ uploads/system/uploads/attachment_data/file/656866/BEIS_ Update_of_Domestic_Cost_Assumptions_031017.pdf

Pelsmakers. (2016). Pre-1919 suspended timber ground floors in the UK: Estimating in-situ U-values and heat loss reduction potential of interventions. London: Doctor of Philosophy. University College London.

Pelsmakers, S., Fitton, R., Biddulph, P., Swan, W., Croxford, B., Stamp, S., ... Elwell, C. A. (2017). Heat-flow variability of suspended timber ground floors: Implications for in-situ heat-flux measuring. Energy and Buildings, 138, 396-405. doi:10.1016/j.enbuild.2016.12.051

Phillips, Y. (2012). Landlords versus tenants: Information asymmetry and mismatched preferences for home energy efficiency. Energy Policy, 45, 112-121. doi:10.1016/j.enpol. 2012.01.067

Roberts, S. (2008). Altering existing buildings in the UK. Energy Policy, 36(12), 4482-4486. doi:10.1016/j.enpol. 2008.09.023

Rodrigues, L., White, J., Gillott, M., Braham, E., \& Ishaque, A. (2018). Theoretical and experimental thermal performance assessment of an innovative external wall insulation system for social housing retrofit. Energy and Buildings, 162, 77-90. doi:10.1016/j.enbuild.2017.10.020

Schiavon, S., Rim, D., Pasut, W., \& Nazaroff, W. W. (2016). Sensation of draft at uncovered ankles for women exposed to displacement ventilation and underfloor air distribution systems. Building and Environment, 96, 228-236. doi:10. 1016/j.buildenv.2015.11.009

Sherman, M. H. (1987). Estimation of infiltration from leakage and climate indicators. Energy and Buildings, 10(1), 81-86. doi:10.1016/0378-7788(87)90008-9

Shorrock, H., \& Utley (2005). Reducing carbon emissions from the UK housing stock, BR 480. Watford.

Siviour, J. B. (1981). Experimental thermal calibration of houses. Conference on Comparative Experimentation of Low Energy Houses, Chateau de Colonster, University of Liege, Belgium, 6-8th May 1981.

Sonderegger, R. C., Condon, P. E., \& Modera, M. P. (1980). In-situ measurements of residential energy performance using electric co-heating; California Univ. Berkeley: Lawrence Berkeley Lab.

Stephen, R. K. (1998). Airtightness in UK dwellings: BRE's test results and their significance. BRE Report 359. Garston: Watford.

Stephen, R. K. (2000). Airtightness in UK dwellings. BRE Information Paper IP 1/00. Garston: Watford.

SWEET. (2014). Retrofit for the future: Analysis of cost data, For the Technology Strategy Board, Final Report.

Ürge-Vorsatz, D., \& Tirado Herrero, S. (2012). Building synergies between climate change mitigation and energy poverty alleviation. Energy Policy, 49(Supplement C), 83-90. doi:10. 1016/j.enpol.2011.11.093

VOA. (2014). Council Tax: property attributes (England and Wales). London: Retrieved from https://www.gov.uk/ government/statistics/council-tax-property-attributes 